\section{EACS}

How to cite this article: Pinto et al. Adherence of community health workers to hepatitis $B$ vaccination. ABCS Health Sci. 2021;46:e021219. https://doi.org/10.7322/ abcshs.2020058.1500

Received: May 26, 2020

Revised: Oct 06, 2020

Approved: Nov 11, 2020

Corresponding author: Flávia Marini Paro - Universidade Federal do Espírito Santo, Centro de Ciências da Saúde, Departamento de Educação Integrada em Saúde - Avenida Maruípe, 1468 - CEP: 29043-900 - Vitória

(ES), Brazil - E-mail: flamarp@yahoo.com

Declaration of interests: nothing to declare

This is an open access article distributed under the terms of the Creative Commons Attribution License.

(C) 2021 The authors

\title{
Adherence of community health workers to hepatitis B vaccination
}

\author{
Paula Kuster Pinto1, Sara dos Santos Amorim¹, Tatiane Silva Rocha1, Lorena Rabelo Feriane', \\ Adauto Vieira de Almeida², Verena Kise Capellini ${ }^{3}$, Flávia Marini Paro ${ }^{4}$ \\ ${ }^{1}$ Curso de Fisioterapia, Universidade Federal do Espírito Santo (UFES) - Vitória (ES), Brazil \\ ${ }^{2}$ Associação de Pacientes da Fila de Transplantes e Transplantados do Espírito Santo - Vitória (ES), \\ Brazil \\ ${ }^{3}$ Departamento de Biociências, Instituto de Saúde e Sociedade, Universidade Federal de São Paulo \\ (UNIFESP) - Santos (SP), Brazil \\ ${ }^{4}$ Departamento de Educação Integrada em Saúde, Centro de Ciências da Saúde (UFES) - Vitória \\ (ES), Brazil
}

\section{ABSTRACT}

Introduction: Hepatitis B (HB) vaccination for health-care workers is essential for World Health Organization's goals achievement of viral hepatitis $(\mathrm{VH})$ elimination. However, recent studies showed low vaccination adherence by these professionals and lack of knowledge about $\mathrm{HB}$ vaccination adherence of community health workers (CHW). Objective: To identify the adherence of $\mathrm{CHW}$ to $\mathrm{HB}$ vaccination; to determine the causes of non-adherence; to investigate whether the prevalence of vaccination is different among surveyed towns, and to verify whether years practiced as CHW have any association with vaccination adherence. Methods: This cross-sectional study included five towns $(\mathrm{T})$ of a Brazilian state. Data were collected at VH educational meetings, in which $\mathrm{CHW}$ answered a questionnaire. The proportions Z-test and the likelihood ratio test were used for statistical analysis. Significance was set at $\mathrm{p}<0.05$. Results: The sample included $516 \mathrm{CHW}$. Most CHW (86.8\%) reported to have taken the vaccine, but only $59.7 \%$ affirmed having taken all doses, and $28.1 \%$ correctly answered the number of doses. $24.4 \%$ of CHW pointed the unknowing about HB vaccine importance as the main reason for non-adherence. T4 and T5 showed higher vaccination prevalence than T2 and T1. Vaccination adherence was higher among individuals with more years working as $\mathrm{CHW}$. Conclusion: $\mathrm{CHW}$ demonstrated low adherence to $\mathrm{HB}$ vaccination and pointed the lack of knowledge about $\mathrm{HB}$ vaccine importance as the main reason for that. There were differences in vaccination prevalence among the towns and adherence was positively associated with professional experience.

Keywords: hepatitis B; community health workers; immunization; epidemiology; health education; education, continuing

\section{INTRODUCTION}

Viral hepatitis $(\mathrm{VH})$ is a serious international public health challenge. World Health Organization (WHO) considers the $\mathrm{VH}$ a pandemic that causes 1.4 million annual deaths worldwide, but its impact is underestimated in many countries ${ }^{1}$.

In order to eliminate $\mathrm{VH}$ as a threat to public health by 2030 , WHO published the first global health sector strategy on $\mathrm{VH}^{1}$, with a particular focus on hepatitis $\mathrm{B}(\mathrm{HB})$ and $\mathrm{C}$ (HC), due to their high morbidity and mortality ${ }^{1,2}$. The tools needed to move towards 
elimination goals already exist: an effective vaccine for $\mathrm{HB}$ and a curative treatment for $\mathrm{HC}^{2}$. Therefore, the achievement of WHO goals is feasible, since political actions are done to increase prevention, diagnosis and treatment programmes ${ }^{2}$.

Vaccination against HB must be universal for all children. WHO recommends that at least three doses of the vaccine must be standardized in national vaccination programs, with the administration of the first dose shortly after birth ${ }^{3,4}$. In addition, vaccination of health-care workers and other high-risk adults is essential for the achievement of $\mathrm{VH}$ elimination goals ${ }^{1,3}$. It is important to note that $\mathrm{HB}$ represents one of the most important occupational risks for health-care workers ${ }^{5}$.

$\mathrm{HB}$ vaccination of health-care workers is almost uniformly implemented across Europe, since it has been recommended for more than three decades ${ }^{6}$. A survey conducted in 2018 to investigate changes in national vaccination policies for health-care workers in Europe showed that vaccination policies against HB were present in 35 of 36 studied countries: 15 countries recommend $\mathrm{HB}$ vaccine for all health-care workers. From these 15 countries, one also mandates $\mathrm{HB}$ vaccine for all health-care workers to get hired and two also mandate $\mathrm{HB}$ vaccine for specific health-care personnel groups or settings; six countries recommend HB vaccine for specific health-care personnel groups or setting; eight countries mandate $\mathrm{HB}$ vaccination for all health-care workers; two countries mandate $\mathrm{HB}$ vaccination as a prerequisite for all health-care personnel to be hired; and four countries mandate $\mathrm{HB}$ vaccination for specific health-care personnel groups or setting ${ }^{6}$.

In Brazil, $\mathrm{HB}$ vaccination is recommended and freely available for all health-care workers, in three doses, that should be repeated if the long-term immunological protection is not confirmed by the serological test of antibody (anti-HBs) against hepatitis B virus surface antigen (HBsAg) ${ }^{7}$. Despite this, Brazilian surveys have showed inadequate adherence of health-care professionals to HB vaccination $^{8-11}$. Recent publications report important differences in $\mathrm{HB}$ vaccination adherence among the countries ${ }^{12-17}$.

In the last few years, the number of publications about $\mathrm{HB}$ vaccination prevalence has grown exponentially due to the importance of regional knowledge about this issue in order to achieve the WHO goals ${ }^{8-17}$. However, few studies have investigated HB vaccination prevalence in community health workers $(\mathrm{CHW})^{8-10}$, who take a privileged position in the dynamics of implantation and consolidation of the Brazilian healthcare system, because they link the community to the health service, being fundamental to primary healthcare policies ${ }^{18}$.

Therefore, the objectives of this study were: 1 ) to identify the adherence of $\mathrm{CHW}$ to $\mathrm{HB}$ vaccination; 2) to determine the causes of non-adherence to $\mathrm{HB}$ vaccination; 3 ) to investigate whether the vaccination prevalence is different among the surveyed towns; and 4) to verify whether the number of years practiced as CHW has association with $\mathrm{HB}$ vaccination adherence.

\section{METHODS}

This cross-sectional study, with a quantitative approach, was carried out from April 2016 to April 2017, in five towns (T) of Espírito Santo, a Brazilian state.

The study population consisted of CHW, from both sexes, with a minimum age of 18 years and from the five surveyed towns who attended in $\mathrm{VH}$ educational meetings, agreed to voluntarily participate in the research and signed the Informed Consent Form (ICF). As the presence at the educational meeting was not mandatory, this study was based on a convenience sample. The exclusion criteria were $\mathrm{CHW}$ who left the $\mathrm{VH}$ educational meetings before the end or who did not return the filled questionnaire to the researcher.

The number of $\mathrm{CHW}$ who attended in $\mathrm{VH}$ educational meetings in T1, T2, T3, T4 and T5 was 200, 155, 83, 162 and 65, respectively; and the number of $\mathrm{CHW}$ who returned the questionnaires to the researcher was $109,118,67,161$ and 61 , respectively; resulting in a participation rate of 54.5, 76.12, 80.72, 99.38 and $93.84 \%$ in T1, T2, T3, T4 and T5.

The $\mathrm{VH}$ educational meetings were part of a major $\mathrm{VH}$ educational program, aimed to aware and update $\mathrm{CHW}$ about $\mathrm{VH}$, planned and conducted by a non-governmental organization from Espírito Santo. These educational meetings, previously scheduled with each Municipal Health Department for the most convenient day and month, were done in two different periods of the same day in each town and all $\mathrm{CHW}$ were shifted from their routine work to attend the $\mathrm{VH}$ meeting. Each meeting took about four hours and consisted of lectures discussing A, B, C and D hepatitis transmission mechanisms and prevention, the need for screening and early diagnosis, and complications of $\mathrm{VH}$ chronic evolution.

Data were collected in the same meeting days and on the same auditoriums where the meetings were held. Immediately before the $\mathrm{VH}$ meeting, the CHW received the ICF, which was read aloud by the responsible researcher, and everyone had the opportunity to clarify their doubts. After that, $\mathrm{CHW}$, who agreed to participate in the study, signed the ICF and returned it to the researcher. At the end of VH meetings, each participant received one printed version of the questionnaire and all of them were instructed to answer it individually (without parallel conversation) and following the researcher reading. Then, each question was read aloud by the researcher, while the participants kept up with the reading in their printed version and enough time were given to them to answer that question in silence, before the following question was read. Considering previous experiences in applying questionnaires to $\mathrm{CHW}$, this data collection method facilitates the comprehension of all participants and avoid interferences in individual responses, reducing potential sources of bias. After questionnaires were filled, they were given to the researcher. According to exclusion criteria, CHW who did not return the questionnaires to the researcher were excluded from the study.

The questionnaire contained two open questions (1- How long have you been working as CHW? and 2- In which town do you work as CHW?) and four closed questions (1- Did you take the 
vaccine against hepatitis B? Answer options: a- Yes; b- No; c- I don't know; 2- Did you take all the doses? Answer options: a- Yes, b- No, c- I don't know; 3- How many doses did you take? Answer options: a- One, b- Two, c- Three, d- Four, e- I don't know; and 4- If you did not take the hepatitis B vaccine or did not take all the doses, why not? Answer options: a- I do not intend to take it because I do not consider it is important, $\mathrm{b}$ - I do not intend to take it because I do not like to take any vaccine, c- I did not know the importance, but now I know and I will take it, d- I did not have time, e- When I went to take it, the vaccine was not available, $\mathrm{f}$ - Another reason).

The statistical analysis was performed using the Statistical Package for Social Sciences (SPSS) 20 (IBM, Armonk, NY, United States) software. All the variables were assumed as categorical (adherence to vaccination, number of doses, causes of non-adherence to $\mathrm{HB}$ vaccination, and the number of years practiced as $\mathrm{CHW}$ ) and were expressed in absolute and relative frequencies. The proportions test (Z-test) was used to compare the percentages of CHW who took the vaccine and who took all doses of the vaccine among the surveyed towns. The likelihood ratio test was used to assess the association between number of years practiced as $\mathrm{CHW}$ and adherence to vaccination. Significance was set at $\mathrm{p}<0.05$.

This study was approved by the Research Ethics Committee of the Universidade Federal do Espírito Santo (Approval number 1.471.400/2016) and all procedures were carried out following the 466/12 Resolution of National Health Council. In order to preserve the data confidentiality, the towns were identified, in this paper, with the letter T followed by an Arabic number of 1 to 5 (T1, T2, T3, T4 and T5).

\section{RESULTS}

The sample included $516 \mathrm{CHW}$. Most CHW (86.8\%) reported to have taken the $\mathrm{HB}$ vaccine, but only $59.7 \%$ affirmed having taken all doses, and yet, only $28.1 \%$ correctly answered the number of $\mathrm{HB}$ vaccine doses. T5 was the unique town where all $\mathrm{CHW}$ declared to have taken the $\mathrm{HB}$ vaccine, even so, only $67.2 \%$ confirmed to have taken all doses and only $39.3 \%$ got the number of doses right (Table 1 ).

A large amount of $\mathrm{CHW}(48.3 \%)$ did not report the reasons why they were not vaccinated or did not take all vaccine doses, but

Table 1: Answers of CHW to the questionnaire about hepatitis B vaccination in five towns. Espírito Santo, Brazil, 2017.

\begin{tabular}{|c|c|c|c|c|c|c|c|}
\hline \multicolumn{2}{|l|}{ Questionnaire } & \multicolumn{5}{|c|}{ Absolut frequencies (Relative frequencies) } & \multirow{2}{*}{ Total } \\
\hline \multirow{2}{*}{ Questions } & \multirow{2}{*}{ Answers } & T1 & T2 & T3 & T4 & T5 & \\
\hline & & $109(21.1)$ & $118(22.9)$ & $67(13.0)$ & $161(31.2)$ & $61(11.8)$ & $516(100.0)$ \\
\hline \multirow{3}{*}{$\begin{array}{l}\text { How long have you } \\
\text { been working as } \\
\text { CHW? }\end{array}$} & $\leq 5$ years. & $50(45.9)$ & $44(37.3)$ & $24(35.8)$ & $27(16.8)$ & $24(39.3)$ & 169 (32.8) \\
\hline & $>5$ years. & $57(52.3)$ & $69(58.5)$ & $38(56.7)$ & $127(78.9)$ & $33(54.1)$ & $324(62.8)$ \\
\hline & Without answer. & $2(1.8)$ & $5(4.2)$ & $5(7.5)$ & $7(4.3)$ & $4(6.6)$ & $23(4.5)$ \\
\hline \multirow{4}{*}{$\begin{array}{l}\text { Did you take the } \\
\text { vaccine against } \\
\text { hepatitis B? }\end{array}$} & Yes. & $86(78.9)^{\mathrm{a}}$ & $94(79.7)^{\mathrm{a}}$ & $58(86.6)^{\mathrm{a}, \mathrm{b}}$ & $149(92.5)^{\mathrm{b}}$ & $61(100.0)^{b}$ & $448(86.8)$ \\
\hline & No. & $8(7.3)^{\mathrm{a}}$ & $23(19.5)^{b}$ & $7(10.4)^{a, b}$ & $0(0)^{a}$ & $0(0)^{\mathrm{a}}$ & $38(7.4)$ \\
\hline & I don't know. & $15(13.8)^{\mathrm{a}}$ & $0(0)^{a}$ & $2(3.0)^{\mathrm{a}}$ & $12(7.5)^{a}$ & $0(0)^{a}$ & $29(5.6)$ \\
\hline & Without answer. & $0(0)$ & $1(0.8)$ & $0(0)$ & $0(0)$ & $0(0)$ & $1(0.2)$ \\
\hline \multirow{4}{*}{$\begin{array}{l}\text { Did you take all } \\
\text { the doses? }\end{array}$} & Yes. & $53(48.6)^{\mathrm{a}}$ & $66(55.9)^{a, b}$ & $37(55.2)^{\mathrm{a}, \mathrm{b}}$ & $111(68.9)^{\mathrm{b}}$ & $41(67.2)^{a, b}$ & $308(59.7)$ \\
\hline & No. & $6(5.5)^{\mathrm{a}}$ & $13(11.0)^{\mathrm{a}}$ & $6(9.0)^{\mathrm{a}}$ & $7(4.3)^{\mathrm{a}}$ & $4(6.6)^{\mathrm{a}}$ & $36(7.0)$ \\
\hline & I don't know. & $25(22.9)^{b}$ & $0(0)^{a}$ & $7(10.4)^{a, b}$ & $11(6.8)^{a}$ & $5(8.2)^{a, b}$ & $48(9.3)$ \\
\hline & Without answer. & $25(22.9)$ & 39 (33.1) & $17(25.4)$ & 32 (19.9) & $11(18.0)$ & $124(24.0)$ \\
\hline \multirow{6}{*}{$\begin{array}{l}\text { How many doses } \\
\text { did you take? }\end{array}$} & One. & $0(0)$ & $2(1.7)$ & $0(0)$ & $3(1.9)$ & $0(0)$ & $5(1.0)$ \\
\hline & Two. & $1(0.9)$ & $9(7.6)$ & $2(3.0)$ & $1(1.6)$ & $1(1.6)$ & $14(2.7)$ \\
\hline & Three. & 15 (13.8) & $50(42.4)$ & $18(26.9)$ & $38(23.6)$ & 24 (39.3) & $145(28.1)$ \\
\hline & Four. & $1(0.9)$ & $0(0)$ & $0(0)$ & $0(0)$ & $0(0)$ & $1(0.2)$ \\
\hline & I don't know. & $4(3.7)$ & $0(0)$ & $0(0)$ & $0(0)$ & $1(1.6)$ & $5(1.0)$ \\
\hline & Without answer. & $88(80.7)$ & $57(48.3)$ & $47(70.1)$ & 119 (73.9) & $35(57.4)$ & $346(67.1)$ \\
\hline \multirow{7}{*}{$\begin{array}{l}\text { If you did not take } \\
\text { the hepatitis } B \\
\text { vaccine or did not } \\
\text { take all the doses, } \\
\text { why not? }\end{array}$} & $\begin{array}{l}\text { I do not intend to take it because I } \\
\text { do not consider it is important. }\end{array}$ & $1(1.8)$ & $0(0)$ & $0(0)$ & $0(0)$ & $0(0)$ & $1(0.5)$ \\
\hline & $\begin{array}{l}\text { I do not intend to take it because I } \\
\text { do not like to take any vaccine. }\end{array}$ & $0(0)$ & $1(1.9)$ & $0(0)$ & $0(0)$ & $0(0)$ & $1(0.5)$ \\
\hline & $\begin{array}{l}\text { I did not know the importance, but } \\
\text { now I know and I will take it. }\end{array}$ & 22 (39.3) & $16(30.2)$ & $6(20.0)$ & $5(10.0)$ & $2(10.0)$ & $51(24.4)$ \\
\hline & I did not have time. & $1(1.8)$ & $4(7.5)$ & $1(3.3)$ & $0(0)$ & $0(0)$ & $6(2.9)$ \\
\hline & $\begin{array}{l}\text { When I went to take it, the vaccine } \\
\text { was not available. }\end{array}$ & $1(1.8)$ & $7(13.2)$ & $4(13.3)$ & $5(10.0)$ & $0(0)$ & $17(8.1)$ \\
\hline & Another reason. & $10(17.9)$ & $5(9.4)$ & $5(16.7)$ & $11(22.0)$ & $1(5.0)$ & $32(15.3)$ \\
\hline & Without answer. & $21(37.5)$ & $20(37.7)$ & $14(46.7)$ & $29(58.0)$ & $17(85.0)$ & $101(48.3)$ \\
\hline
\end{tabular}

T: town; CHW: community health workers; the percentages of $\mathrm{CHW}$ who had taken the vaccine and who had taken all doses of vaccine were compared among the five towns using Z-test and statistically significant differences were indicated by superscripted letters, where the letter ${ }^{b}$ means greater proportion than the letter a 
$24.4 \%$ of $\mathrm{CHW}$ pointed the not knowing about the importance of HB vaccine as the main reason (Table 1 ).

In the comparison among the towns, $\mathrm{T} 4$ and $\mathrm{T} 5 \mathrm{had}$ a higher percentage of CHW who answered "Yes" to the question "- Did you take the vaccine against hepatitis B?" than T1 and T2. Regarding the question “- Did you take all the doses?” T4 had higher percentage of CHW who answered "Yes" than T1 (Table 1).

Considering that both questions "Did you take the vaccine against hepatitis B?" and "Did you take all the doses?" represent vaccination adherence, it was observed that vaccination adherence was higher among $\mathrm{CHW}$ with more than 5 years of experience in comparison to $\mathrm{CHW}$ with equal or less than 5 years of working time (Table 2).

\section{DISCUSSION}

Low adherence to $\mathrm{HB}$ vaccination was observed among the CHW from the five towns included in this study, as just over half (59.7\%) of the CHW reported to have taken all doses of the vaccine. Low prevalence of vaccination was also observed in two towns located in other Brazilian states, one town in Minas Gerais state $^{9}$ and another in Bahia state ${ }^{8}$ that showed $41.0 \%$ and $65.3 \%$ of CHW having completed the $\mathrm{HB}$ vaccination standard, respectively. Such data are worrisome, considering that the $\mathrm{WHO}^{3}$ and the Brazilian Ministry of $\mathrm{Health}^{7}$ recommend $100 \%$ vaccination against $\mathrm{HB}$ among health workers, since lack of vaccination exposes these professionals to the risk of $\mathrm{HB}$ virus (HBV) infection ${ }^{3,5,12,13}$.

In addition, the majority (67.1\%) of the CHW did not answer the question "How many doses did you take?" perhaps due to the fear about their wrong answers reveal the lack of knowledge regarding the number of doses required for immunization. Reinforcing this hypothesis of not knowing that three doses are necessary to immunization, it was also observed that although $59.7 \%$ of $\mathrm{CHW}$ affirmed to have taken all the doses, only $28.1 \%$ said to have taken the three doses. Then, if only $28.1 \%$ of the CHW have taken the three doses, the vaccination prevalence against $\mathrm{HB}$ among the $\mathrm{CHW}$ of the present study is overestimated.

It is worth mentioning that the protective efficacy of $\mathrm{HB}$ vaccine is characterized by presence of IgG antibodies to HBsAg after completion of vaccination series ${ }^{3,7,19}$. In a serological exam done one to two months after the last dose of the vaccination schedule, the anti-HBs concentration $\geq 10 \mathrm{mIU} / \mathrm{mL}$ is considered a reliable marker of long-term protection ${ }^{3,19}$. Routine post-vaccination anti-HBS test is not necessary, but must be considered for people presenting occupational risk of exposure to HBV infection, like health-care workers ${ }^{3}$. However, the post-vaccination test adherence is poor among health workers ${ }^{8,20}$.

The unknowing about the importance of $\mathrm{HB}$ vaccine, alleged by the $\mathrm{CHW}$ as the main reason why they did not taken the vaccine, deserves attention because it does not match the functions of these professionals who occupy a strategic place in health promotion and disease prevention ${ }^{18,21}$. Their functions vary a lot between health teams and regions ${ }^{18,21,22}$, but communication, health education, and health surveillance ${ }^{21}$ can be pointed as crucial for immunization process. The CHW have been considered the most effective professional to communicating with the community, being described by primary health managers as fundamental in the communication between health departments and the population ${ }^{23}$. Their health education actions involve lectures ${ }^{18,22}$ and home visits in the community ${ }^{18,21,22}$. During home visits, which are considered a central activity in the work process of $\mathrm{CHW}^{18,21,22}$, these professionals register the families, weigh children, follow up people with prevalent diseases, deliver and guide the use of medicines, check the vaccination card, check the home/environment conditions, actively search for absentees, advise on health services, among other actions $^{22}$. Therefore, it is essential for CHW to be trained to advise the population on $\mathrm{HB}$ vaccination and to actively search, in their action territory, for vulnerable groups and all people who started, but did not complete the vaccination scheme. Indeed, health professionals play a key role in stimulating and maintaining the population's trust in vaccination and advising the parents about their concerns on this issue ${ }^{24}$. Universal childhood vaccination against $\mathrm{HB}$ and vaccination of the most vulnerable groups are essential for interrupting the disease transmission chain ${ }^{1,3}$ and vaccination is considered the most important strategy to eliminate $\mathrm{HB}$ until $2030^{1-3}$. The vaccination against $\mathrm{HB}$ is projected to have prevented 310 million cases of HB between 1990 and $2020^{4}$.

Table 2: Association between number of years practiced as community health worker and adherence to hepatitis $B$ vaccination in five towns. Espírito Santo, Brazil, 2017.

\begin{tabular}{|c|c|c|c|c|}
\hline \multicolumn{2}{|l|}{ Questionnaire } & \multicolumn{2}{|c|}{$\begin{array}{l}\text { Absolut frequencies } \\
\text { (Relative frequencies) }\end{array}$} & \multirow[b]{2}{*}{$\mathbf{p}$} \\
\hline Questions & Answers & $\begin{array}{l}\text { Time of working } \\
\leq 5 \text { years }\end{array}$ & $\begin{array}{l}\text { Time of working } \\
>5 \text { years }\end{array}$ & \\
\hline \multirow{3}{*}{$\begin{array}{l}\text { Did you take the vaccine against } \\
\text { hepatitis } B \text { ? }\end{array}$} & Yes. & $136(80.5)$ & $291(90.1)$ & \multirow{3}{*}{0.011} \\
\hline & No. & $20(11.8)$ & $17(5.3)$ & \\
\hline & I don't know. & $13(7.7)$ & $15(4.6)$ & \\
\hline \multirow{3}{*}{ Did you take all the doses? } & Yes. & $82(67.8)$ & $210(82.7)$ & \multirow{3}{*}{0.006} \\
\hline & No. & 17 (14.0) & $18(7.1)$ & \\
\hline & I don't know. & $22(18.2)$ & $26(10.2)$ & \\
\hline
\end{tabular}

The association between number of years practiced as community health worker and adherence to vaccination was tested using the likelihood ratio test. 
In Brazil, $\mathrm{HB}$ vaccination efforts changed the country's $\mathrm{HB}$ endemicity status from intermediate to low, although marked regional differences still persist ${ }^{25}$. It is important to note that, in the southeastern region of Brazil, where Espírito Santo state is located, the population's adherence to HB vaccination scheme is still insufficient, although it has increased in recent years ${ }^{26}$.

In the present study, some small differences among towns were also observed. T4 and T5 had higher percentage of CHW affirming to have taken the vaccine than $\mathrm{T} 1$ and $\mathrm{T} 2$. In T5, all CHW reported to have taken the vaccination, however, among these CHW from T5, only $67.2 \%$ confirmed to have taken all the doses. The vaccination prevalence of $68.9 \%$ in $\mathrm{T} 4$, although statistically higher than the prevalence observed in T1, remains inadequate. Regional differences in vaccination prevalence were expected ${ }^{25,26}$, but the results of the present study are useful to show that these differences occur not only between different regions or states, but also between neighbor towns located in the same state. These local characteristics must be considered when strategies to increase vaccination prevalence are planned. It is worth saying that the towns' names were not revealed to maintain confidentiality about the surveyed professionals, but the data for each town will be presented to its Health Department, so appropriate measures could be taken.

The present results showed association between number of years practiced as $\mathrm{CHW}$ and adherence to $\mathrm{HB}$ vaccination, since vaccination adherence was higher among $\mathrm{CHW}$ with more than 5 years of experience compared with those with less worked years. Similar relationship was also observed in professionals working in Family Health Strategy Program, and although the sample of that study had not been restricted to CHW, these professionals were also included ${ }^{9}$. A recent systematic review about $\mathrm{HB}$ vaccination coverage among health-care workers in Africa also demonstrated that professionals with more years of experience were more likely to be vaccinated ${ }^{14}$. This expected association could be explained by the supposition of professional experience improves the knowledge and greater knowledge has been associated with higher adherence to vaccination among health professionals ${ }^{8,9,16}$ and the population in general ${ }^{27}$. In addition, it can be assumed that a longer time working as CHW has provided more opportunities for these professionals to be vaccinated and to participate in training about VH. In spite of these results be expected, it is essential for $\mathrm{HB}$ prevention that all health professionals be vaccinated before initiate contact with patients ${ }^{3}$, therefore health policies should institute more educational programs, like training about $\mathrm{VH}$, and establish rules for earlier vaccination in health professionals, such as mandatory vaccination to professional be hired.

This study has some limitations. First, the data collection was based on a self-reported questionnaire instead of on an inspection of vaccination cards, allowing participants to give non-real answers. Then, the adherence of $\mathrm{CHW}$ to $\mathrm{HB}$ vaccination may have been overrated or underestimated. Second, it was carried out with a convenience sample from towns belonging to the same state of the federation, limiting the generalization of results.

In conclusion, $\mathrm{CHW}$ demonstrated low adherence to $\mathrm{HB}$ and reported lack of knowledge about the importance of vaccination against $\mathrm{HB}$ as the main cause of non-adherence to $\mathrm{HB}$ vaccination. There were differences in vaccination prevalence among the surveyed towns. Furthermore, the adherence to $\mathrm{HB}$ vaccination was positively associated with years of professional experience. This scenario is concerning given that the lack of adherence to the vaccine puts the health of these professionals at risk. Therefore, strategies are needed to raise awareness about $\mathrm{HB}$ as well as to increase vaccination coverage in CHW. These strategies should not be restricted to, but should include training program at the initial formation of $\mathrm{CHW}$ and effective $\mathrm{HB}$ continuing education. The differences observed among the towns highlight the importance of knowing and considering specificities of each health service in order to design effective strategies.

\section{REFERENCES}

1. World Health Organization (WHO). Global Health Sector Strategy on Viral Hepatitis, 2016-2021. Available from: http://apps.who.int/ iris/bitstream/10665/246177/1/WHO-HIV-2016.06-eng.pdf.

2. The Lancet. Eliminating viral hepatitis: time to match visions with action. Lancet. 2017;390(10108):2121 https://doi.org/10.1016/S0140-6736(17)32856-8

3. World Health Organization (WHO). Hepatitis B vaccines: WHO position paper, July 2017-Recommendations. Vaccine. 2019;37(2):223-5.

https://doi.org/10.1016/..vaccine.2017.07.046

4. Cooke GS, Andrieux-Meyer I, Applegate TL, Atun R, Burry JR, Cheinquer $\mathrm{H}$, et al. Accelerating the elimination of viral hepatitis: a Lancet Gastroenterology \& Hepatology Commission. Lancet Gastroenterol Hepatol. 2019;4(2):135-84. https://doi.org/10.1016/S2468-1253(18)30270-X
5. O'Brien CR, Lim JK. Prevention and Management of Hepatitis B in Healthcare Professionals. Curr Hepatol Rep. 2019;18:1-8. https://doi.org/10.1007/s11901-019-00444-6

6. Maltezou HC, Botelho-Nevers E, Brantsæter AB, Carlsson RM, Heininger $U$, Hübschen JM. Vaccination of healthcare personnel in Europe: Update to current Policies. Vaccine. 2019;37(52):7576:84. https://doi.org/10.1016/j.vaccine.2019.09.061

7. Brasil. Ministério da Saúde. Secretaria de Vigilância em Saúde. Coordenação Geral de Desenvolvimento da Epidemiologia em Serviços. Guia de vigilância em Saúde: volume único. 2ed. Brasília: Ministério da Saúde, 2017.

8. Souza FO, Freitas PSP, Araújo TM, Gomes MR. Vacinação contra hepatite B e Anti-HBS entre trabalhadores da saúde. Cad Saude Coletiva. 2015;23(2):172-9.

http://doi.org/10.1590/1414-462X201500020030 
9. Costa FM, Martins AMEBL, Santos Neto PE, Veloso DNP, Magalhães VS, Ferreira RC. Is vaccination against hepatitis B a reality among Primary Health Care workers? Rev Latino-Am Enfermagem. 2013;21(1):316-24.

https://doi.org/10.1590/S0104-11692013000100005

10. Martins AMEBL, Costa FM, Ferreira RC, Santos-Neto PE, Magalhaes TA, Sá MAB et al. Factors associated with immunization against Hepatitis B among workers of the Family Health Strategy Program. Rev Bras Enferm. 2015;68(1):84-92. https://doi.org/10.1590/0034-7167.2015680112p

11. Araújo TM, Souza FO, Pinho PS. Vaccination and associated factors among health workers. Cad Saude Publica. 2019;35(4):e00169618. https://doi.org/10.1590/0102-311×00169618

12. Mursy SMM, Mohamed SOO. Knowledge, attitude, and practice towards Hepatitis B infection among nurses and midwives in two maternity hospitals in Khartoum, Sudan. BMC Public Health. 2019;19:1597. https://doi.org/10.1186/s12889-019-7982-8

13. Tian J, Tan, F, Lai L, Deng Y, Chi X, Geng H, et al. Anesthesiologists' acquisition of hepatitis $B$ virus infection: Risk and prevention. Medicine (Baltimore). 2019;98(29):e16416 http://dx.doi.org/10.1097/MD.0000000000016416

14. Auta A, Adewuyi EO, Kureh GT, Onoviran N, Adeloye D. Hepatitis $B$ vaccination coverage among health-care workers in Africa: $A$ systematic review and meta-analysis. Vaccine. 2018;36(32):485160.

https://doi.org/10.1016/j.vaccine.2018.06.043

15. Radia A, Amina H, Raihan B, Hajar S, Nabila S. Hepatitis B Screening and Evaluation of Hepatitis B Vaccination Status Among Medical Staff at Med VI University Hospital of Marrakech (CHU). Am J Lab Med. 2019;4(4):74-8. https://doi.org/10.11648/j.ajlm.20190404.12

16. Riccó M, Cattani S, Casagranda F, Gualerzi G, Signorelli C. Knowledge, attitudes, beliefs and practices of occupational physicians towards vaccinations of health care workers: A cross sectional pilot study in North-Eastern Italy. Int J Occup M Environ Health. 2017;30(5):775-90. https://doi.org/10.13075/ijomeh.1896.00895

17. Harrison N, Brand A, Forstner C, Tobudic S, Burgmann K, Burgmann $\mathrm{H}$. Knowledge, risk perception and attitudes toward vaccination among Austrian health care workers: A cross-sectional study. Hum Vaccin Immunother. 2016;12(9):2459-63. http://dx.doi.org/10.1080/21645515.2016.1168959
18. Freitas LM, Coriolano-Marinus MWL, Lima LS, Ruiz-Moreno L. Formação dos agentes comunitários de saúde no município de Altamira (PA), Brasil. ABCS Health Sci. 2015;40(3):171-7. http://dx.doi.org/10.7322/abcshs.v40i3.791

19. Jack AD, Hall AJ, Maine N, Mendy M, Whittle HC. What level of hepatitis B antibody is protective? J Infect Dis. 1999;179(2):48992.

https://doi.org/10.1086/314578

20. Lopes MH, Sartori AM, Souza TV, Mascheretti M, Chaves TS Hepatitis $B$ revaccination for healthcare workers who are anti-HBsnegative after receiving a primary vaccination series. Rev Soc Bras Med Trop. 2012;45(5):639-42. https://doi.org/10.1590/S0037-86822012000500018

21. Araújo MRN, Assunção RS. A atuação do agente comunitário de saúde na promoção da saúde e na prevenção de doenças. Rev Bras Enferm. 2004;57(1):19-25. https://doi.org/10.1590/S0034-71672004000100004

22. Nunes CA, Aquino R, Medina MG, Vilasbôas ALQ, Pinto Júnior EP, Luz LAD. Visitas domiciliares no Brasil: características da atividade basilar dos Agentes Comunitários de Saúde. Saude Debate. 2018;42:127-44 https://doi.org/10.1590/0103-11042018S209

23. Velho APM, Vermelho SCSD, Lucena TFR, Bortolozzi F, Bennemann RM. Estratégias de comunicação das Secretarias Municipais de Saúde: desafios para as Redes de Atenção à Saúde. Saude Pesqui. 2018;11(3):505-15.

https://doi.org/10.17765/2176-9206.2018v11n3p505-515

24. Leask J, Kinnersley P, Jackson C, Cheater F, Bedford H, Rowles G. Communicating with parents about vaccination: a framework for health professionals. BMC Pediatr. 2012;12(1):154. https://doi.org/10.1186/1471-2431-12-154

25. Souto FJ. Distribution of hepatitis B infection in Brazil: the epidemiological situation at the beginning of the 21st century. Rev Soc Bras Med Trop. 2016;49(1):11-23. http://dx.doi.org/10.1590/0037-8682-0176-2015

26. Melo MC, Jacob LMS, Cabral ERM, Rolim ACA. Variação anual percentual de doses vacinais para hepatite B na região Sudeste do Brasil. Rev Prev Infec Saude. 2018;4:7028. https://doi.org/10.26694/repis.v4i0.7028

27. Pereira RGV, Machado JLM, Machado VM, Mutran TJ, Santos LS, Oliveira E, et al. The influence of the knowledge towards the vaccine against Human Papillomavirus: a randomized clinical trial. ABCS Health Sci. 2016;41(2):78-83. http://dx.doi.org/10.7322/abcshs.v41i2.873 